\title{
Socio-Political Transformation of the South Bank of the Gambia: Impact of Ethnic and Clerical Migrations on the South Bank from 1850 to 1889
}

\author{
Ensa Touray
}

\begin{abstract}
This paper intends to explore the geographical, diverse socio-cultural milieu and social and political condition of the south bank of the Gambia. Since the physical features of the area served as a pull factor for human migration, the south bank area became a settlement for Jolas, Mandinkas and Fulas. In addition, it examines the impact of the migration of Muslim clerics and the establishment of Muslim settlements on the social and political structures of the south bank area. Finally, it also highlights the migration of Fulas into the region and the creation of the Fulladu Kingdom as well as the emergence of Foday Kaba Dumbuya and the migration of popular clerics in the Fulladu kingdom.
\end{abstract}

Index Terms-Territory, clerics, dominance, ethnic, migration.

\section{INTRODUCTION}

\section{A. Geographical Setting and the People}

The regional perspective of greater Senegambia indicates that Senegambia as a regional entity extends from the River Gambia to the forest of Guinea (See Fig. 1, the map of the Gambia). ${ }^{1}$ However, as for Gray, based on the earlier political geography shown in the map of D'Anville establishes the geographical scope of south bank area that constitutes the kingdoms of Kantora, Tomani, Jimara, Eropina, Niamina, Jarra, Kiang, Foni and Kombo. [1] Accordingly these were places of diverse socio-cultural elements. The map below shows the modern boundary designed by the British.

According to Gray the region of Foni was inhabited by the Jolas who were also cited as among the earliest inhabitants of The Gambia. They were known by Europeans as Feloop. [1] However, oral tradition among the Manding speaking people confirms that the name Jola signifies the people who pay back whatever was done to them. James Searing outlines the instrumentality of Religion in the process of harmonization in the traditional Jola society. He further explains how internal collective consciousness shaped their religious worldview. His analysis demonstrates

Manuscript received 31 December 2015; revised March 12, 2016.

E. Touray is with the University of The Gambia, The Gambia (e-mail: etouray@utg.edu.gm). ${ }^{1}$ In his book, entitled Senegambia and The Atlantic Slave Trade, Boubacar Barry attempts to define the geographical scope of Senegambia based on the pre-colonial link of the countries such as Senegal, Gambia, Guinea Bissau and Guinea Conakry to the medieval ancient empires of Mali, Ghana, and Songhai. Since all the countries had their cultural, political and economic orientation from those medieval empires in the pre-colonial era, they are considered as part of the greater Senegambia region. Therefore the said places mentioned emerged as a result of the wave of Manding conquest. the set of dogmatic rituals that revolved around "the relationship between the people, the shrine, and "Emitai", the supreme God". [2] It is believed that Emitai was the dominant instrumental force who brought rain and fertility through the performance of specific rituals. In addition, the system of initiation was very instrumental in their process of socialization (Barry, 1998) [3]. The Jolas did not only attach importance to land as a source of sustenance and material possession inherited from their ancestors, but the earth itself was associated with spiritual forces known as bikini, responsible for giving life and health [4].

The ecological reality in the southern bank region of Foni is significant to our understanding of the nature of Jola settlement and the predominant economic activities in Foni. The ecology in Foni had mangrove swamps behind which by palm groves. These were part of a dense network of the creeks which accounted for the southern reach of Senegambia that came to be known as the southern Rivers [3]. The Jolas in this southern region made use of these ecological fortunes to excel in rice and palm wine production. They also used aquatic products, such as shellfish from the creeks, to supplement their diets. The oral tradition in Foni generally confirms that, Serer fishermen from the north bank of the Gambia crossed over Bintang creek to barter their fish products for cereal, tubers and palm oil. $^{2}$

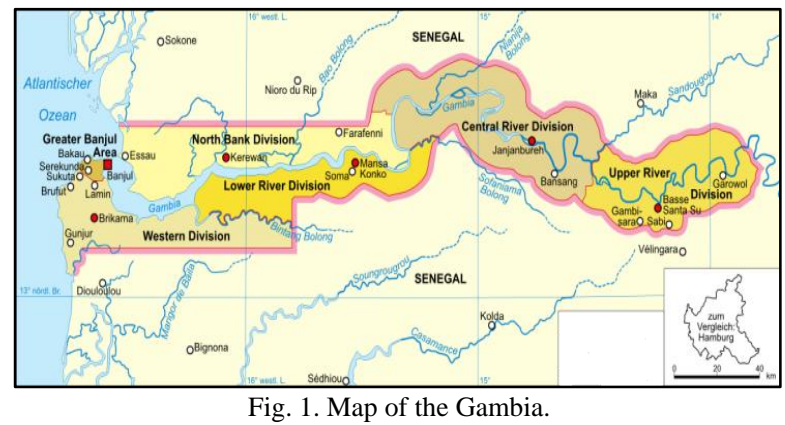

Politically, the Jolas in Foni are categorized under noncentralized populations in the Gambia. They did not form a large-scale political entity. They formed small peasant societies with an egalitarian outlook. In addition, they did not have a class or caste structure [5]. Gamble's characterization of Jolas in Foni does not establish the existence of dominant warriors, chiefs or ruling families. However, Baum's in-depth assessment of warfare and its interrelationship with religious practice among the Jolas is a

\footnotetext{
${ }^{2}$ Sutay Bojang, interview, Sangajour village, 11 January 2009.
} 
sharp contrast to the view of Gamble. It has also given us the idea of the existence of well-trained professional warriors. His study specifically identifies the dependence of Jola warriors on the mystical powers to escape death in war. Therefore, the invocation of spiritual powers to minimize arbitrariness of chance, to cheat fates was to control their own destiny [6].

However, the Bainunkas who were the earliest settlers, briefly established political control in the region of Foni [4]. According to oral sources, Foni was formerly a territory of Bainunkas. Ibrahima Mane Thioub's survey of Casa Bainuň Empire indicates that The Gambia, Casamance and Guinea Bissau were part of vast Bainun̆ Empire called Cassa Bainuň with its capital at Brikama, $53 \mathrm{~km}$ from present day Ziguinchor. Cassa Bainuň was ransacked and invaded by Manding migrants under the leadership of Tiramghan Trawally. ${ }^{3}$ It is eminent in history that the effort of Mali Empire to establish Manding political suzerainty affected both political and cultural geography. As Donald Wright contends, the wave of Manding migration has altered political geography and ethnicities in Senegambia. Many Bainunkas have changed ethnicity due to Mandinka dominance of both social and political structure [7].

The Bainunka showed little interest in war even in the empire of "Kasa" in the sixteenth century. So the Jolas in Foni assimilated their earlier population, and it is over this pacifist orientation that continued to characterize Foni[4]. Significantly, most of the towns and villages in the presentday Foni in the south bank of The Gambia were earlier establishments of the Bainunka people. Their nomenclatures for those settlements still remain in Foni. Sangajour is a present-day Jola settlement, but the elders generally confirm that the earliest founder was a Bainunka man called Ngajour, who was fought and defeated by the Jola migrants. It was from this man that the name Sangajour originated. Another Bainunkas man is also said to be the founder of Bondali. This settlement also became a dominant Jola settlement through intermarriage. It was preserved in the tradition that the migrant Jola elder, Gasamanga, offered the Bainunka man one of his daughters in exchange for the entire settlement. $^{4}$

It is generally noted that ecological factor is a significant issue in the historical discipline relevant to our understanding of human settlement. The availability of rice field along the rivers in Foni did not only serve as pull factor for incoming populations, but also served as potential source of inter ethnic conflict between the Bainunkas and Jolas in Foni. ${ }^{5}$ The tradition in Foni confirms, and even traces most major ethnic conflicts in the region prior to European imperialism, to the competition over the control of strategic and viable ecological zones. Therefore, the

\footnotetext{
${ }^{3}$ The Bañun Casamance: the story of a people the test of external contacts (1828-1901) Presented by Under the direction of Idrissa Ibrahima Mane Thioub Professor, Academic Year 2009-2010 . Tiramghan Trawally was the lieutenant General of the Emperor of Manding Empire in Mali in the $13^{\text {th }}$ century. He was commissioned for westward conquest for Mali Empire within the region of Senegambia.

"According to Bintou Kolly, "Gasamanga Kolly" was a migrant trader from Jipagum in Casamance region.

${ }^{5}$ Mustapha Bojang and the elders of Kanfenda, interview, Kanfenda village, 4 September, 2012.
}

flood recession fields and mangrove swamp in Foni attracted competition between Bainunkas and Jolas.

\section{ETHNiC CONFLICT IN FONI}

Ethnic migration in Foni must be rationalized within context of ecological pull-push model. The region of Foni is situated along Gambian River in the south bank of the Gambia. Its strategic location to the River and swampy mangroves served as potential attraction for struggle over the control of rice field prior to the introduction of legitimate trading system. It is during this period all the flood recession fields in the entire Foni were under the custodianship of Bainunkas. Okwudiba Nnoli in his comparative study of ethnic conflict conceptually defines ethnicity as a phenomenon associated with competition and exclusiveness among ethnic groups which are members of the same political community. [8] The form of inter- ethnic conflict related to Foni is what Samuel G Egwu called agrarian question. [9] It is in this framework of ecological driven conflict, the ethnicity in Foni could be contextualized. The migration of incoming population in Foni generated a threat over custodianship of the flood recession field central to rice cultivation in the Region of Foni. Consequently, the Jola migrant had to use spiritual war to gain upper hand in Kanfenda. They employed the service of priest of the family, known as Buryan Bojang. According to the narration of elders of Kanfenda, Buryan facilitated the invasion of Bojangs in Kanfenda. This military invasion forced two sambu Bainunka families led by Nnomu Sambu and Nyami Sambu to evacuate. Fenda remained to resist this invasion until he was killed and buried. This defeat therefore marked the total control of the area by Bojang Jolas.

In Bwiam another inter-ethnic conflict arose in the context of agrarian question. Here also the Jolas of Nyass and Badjie Jola family made a joint alliance against the Bainunkas. This inter- clan based collaboration enhanced Nyass Family to establish their hegemony, and eventually became the custodian of all rice fields in Bwiam. With the determination of Jolas to control the entire Bwiam area, the Nyassi family compensated Attiti Badjie by allocating the Southern part of Bwiam.

Many of the Jola settlements lacked unity and stability that made them vulnerable to migrant Mandingos [1]. The period of 1820 in the Gambia marked the beginning of cash crop production and the subsequent introduction of monetary economy in The Gambia. Consequently, this gave Gambia a new phase of commercial position, which also required the increase in the internal labour demand in agricultural production [7]. It also led to intensification of internal slavery. During the period of 1820 the British came to realize that most of the Jolas were captured by Mandinka chiefs as slaves. A draft dispatch sent to colonial office reveals the significant roles played by the chiefs in the internal slavery. ${ }^{6}$ After the abolition of Atlantic slave trade, some chiefs continued to employ active measures in the process of procuring slaves from the south bank area, specifically from Foni. It also marked the intensification of

${ }^{6}$ CSO1 The Draft Dispatches to colonial Office , Piece 118, Gambia National Archive, Banjul.(NRS). 
violence that constrains the participation of communities in Foni in cereal production. Gray confirms that women of Foni were kidnapped while working in their rice fields and carried to the mouth of the Saloum River for the purpose of selling them into slavery [1].

Conversely, some traditions confirm places in the south bank area to be under the leadership of Jola kings. These kings were Lumbak Sanyang of Tanduk, Choko Ndene of Wangar and Netehtu Sonko of Kulang Njang. ${ }^{7}$ Peter Mark (2002) also argues that ecology was one of the deterring factors for political unity in most of the Jola countries. As most of the Jola settlements were situated inside the thick forest, it became impossible for easy access and linkages to facilitate the establishment of centralized polity [4].

\section{The Migration OF Clerics AND SOCIO-POLITICAL STRUCTURES IN SOUTH BANK KINGDOMS}

It is important to conceptualize motivations of migration into south bank of Senegambia on the bases of ecological and political factors rationalized within the framework of push-pull model [10]. This model is relevant to our understanding of historical migration patterns on south bank regions of Kiang, Jarra and Kombo. In the case of Muslim clerics, the primary historical reason for migration was to escape political persecution in the northern Senegambia region.

In the mid of nineteenth century the non Muslim ruling elites in the entire western savannah dominated social, political and economic phenomena. This consolidation became a reputed model for aristocratic and despotic behaviours of non-Muslim elites [11]. They re-affirmed their common political and social goal through intermarriage. In the kingdoms of Jarra and Kiang the dominant ethnic groups were the centralized Mandinkas. They established political control over Kiang, Jarra and Niamina. However, the groups of Mandinkas who ruled these places were not Muslims. In spite of their ethnic belonging, Mandinka clerics, who were educated literally and professionally in Islam, considered the traditional Mandinka kings as Soninkes, like Jolas and Bainunkas in the Foni area. ${ }^{8}$ In their areas of influence, the clerical families began to migrate and established isolated settlements known as Moribund [12]. In contrast to the conditions in southern Senegambia region, David Robinson's survey indicates that the practice of Islam in the north created a new socio-political and commercial elites in Islam within territorial and cultural context of Dar al Islam, abode of peace [13]. They also established clerical centers where people came from different areas to take Koranic instruction from the clerical leaders.

In the historiography of Islam in Senegambia, scholars identify two methods in the spread of Islam: the pacific and militant. According to pacifists' point of view, spread of Islam should be conceptualized on the bases of teaching and preaching as the only means of socio-political change. In

\footnotetext{
${ }^{7}$ Generally in Senegambian history Barry and Philip D Curtin categorize Jolas under non-centralized system. Therefore, according both authors politics could be defined in socio-cultural context.

${ }^{8}$ The term Soninke has both ethnic and religious connotations in the Senegambia: it signifies either non-Muslim or nominal Muslims. In other areas it refers to the Sarahule ethnic group.
}

this situation, putting up defensive mechanism as a precondition to facilitate religious practice became a major priority for Muslims. Pacificism was a fundamental attribute of Quadriyaa brotherhood in the Senegambia region. Among the Quadriyaas, there were some clerics like Ahmad Bamba and Jakhankeh clerical group led by Alhaji Salim Suwareh who were prominent for their pacific stance in the course of Islamic revolution [13].

Lamin Saneh [14] traces the Muslim pacific stance for political patronization by secular kings. Accordingly this form of inter-dependence facilitated political and economic security for the Muslim minority within context of Soninke political hegemony. For example, Musa Molloh benefited from Jahanke clerics in his wars against the Muslims and non-Muslims. They gave him prayer services in return for slaves. Around 1850, the Soninke kings in Jarra and Kiang benefited from the services rendered by marabout in the form of prayers and the provision of protective amulets worm by the kings against the penetration of alleged human and spiritual forces.

Charlotte Quinn's survey of Muslim penetration outlines the methods employed by pacifist Muslims in the course of socio-cultural transformation. Muslim clerics explored patronization of socio-cultural practices as transformational capital within dominant non-Muslim Mandinka settlement. The traditional Mandinka religion that was practiced before the migration of Muslim clerics was also affected by the infiltration of Islam in Kiang and Jarra [12]. For example, the practice of communal rites associated with other Manding-speaking people experienced extinction in the latter part of the nineteenth century. For instance, some of the traditional sacred groves were changed and reserved for Muslim circumcision. They also explored a system of alignment as a diplomatic tactics to create division among the Soninke royal houses. It was preserved in the tradition of Kiang that some members of the ruling families converted to Islam through their alignment to Muslim clerics. For example, the last sons of Mamba Sane, King of Genieri, became a friend of Muslims and later converted to Islam. This led to the division of royal families in the Mandinka state of Kiang. ${ }^{9}$

However, militant Islam could also be perceived on the bases of its offensive approach as an instrument of social and political change. This discourse demonstrates the position of Militant Muslims in ensuring that embracing Islam is a precondition of safety for humankind. As a result, non-Muslims may have the state of war declared upon them by Muslims because they are judged to have refused the necessary conditions of freedom of the race of Adam. In this regard, militant Muslims saw non-Muslims as enemies (hurub) living in dar al-harb, i.e the abode of warfare. The Islamic canonical obligation of holy war (Jihad) against unbelievers was at once lawful and obligatory more especially on oppressive pagan aristocracies that were at the helm of government in Senegambia. ${ }^{10}$

\footnotetext{
9 According to Charlotte Quinn some members of ruling houses converted because they had the hope that militant Muslims would avoid them.

${ }^{10}$ J.D. Fage and William Tordoff, History of Africa, Hutchinston \& Co. (Publishers) Ltd 2002, p255-300
} 
The consolidation and power relations in the entire Senegambia region began to change in the middle of $19^{\text {th }}$ century. The Soninke ruling class considered themselves privileged. Donald Wright traces the basis of their dominance to their dependence on the produce of slaves, peasants, and the revenues accrued from the trade that passed through their territories [11]. The ruling authorities constrained all forms of peer and popular check on their administration as required by the tradition. It should be noted that Africa during pre-conquest period, the traditional authorities functioned in an advisory and consultative context. Therefore, the Muslim clerics, farmers and peasants under Soninke regimes in the middle of $19^{\text {th }}$ century became subjects of exploitation without any civic entitlements. [15]

However, the militant clerics were determined to end this political isolation through military alliance system. Olayemi Duro identifies how military alliances were very instrumental in gaining victory in pre-colonial Nigeria. In the south bank of the Gambia, Muslims Jihadist also sought military alliances to threatened and weakened the traditional political authorities.

As Soninke continued to constitute the dominant force in the south bank area of Senegambia, the Muslim minorities began to establish alliances and collaborate with each other. 1860 s is another political turning point on both banks of Gambia. Wright rationalizes the period as the beginning of practical manifestation of dissatisfaction among Muslims, and therefore argues that the reformist urge among Muslims was very strong [11]. The reformist reactions need to be contextualized within framework of global system analysis. It should be understood that prior to abolition of Atlantic slave trade, two major regional political entities like Kabu and Futa Imamate actively participated in the Trans-Atlantic slave trade, owing to their control of strategic ecological zones and Rivers. And the American victory in the war of independence led to shift in western European sources of tropical products and the desire for market. This led to introduction of legitimate trading system with cash crop production. Significantly, ecological realities of Futa Jallon region could not avail Futa to gain control over new production system due to geological nature of the land scape. However, viable ecological zones with arable land for peanut production were within the territorial jurisdictions of Kubu, non Muslim Mandinka dominated empire. In this situation Kabu was still benefiting from the new trading system. Barry analyzes the change in the international economic system as a motivation for the expansionist drive of Futa for her global participation within the framework of legitimate trading system. Following the invasion and downfall of Kabu, Futa Imamate, through the administrative province of Labe, brought three political power centers under their suzerainty: First, Firdu under the control of Alfa Moolo; second, Foria, under Bakar Demba; and the third, in Kabu under Bakary Qidali [3].

Geographically, the region of Kombo is located on the Atlantic coast of Gambia River. Prior to expansion of Mali, the entire Kombo was inhabited by Bainunkas and Karoni speaking people. Kombo came under the hegemony of Manding speaking people through the intervention of Kabu Empire, the regional power. However, David E. Skinner's survey establishes the pivotal roles of The Gambia River as an ancient trade route and magnet for populations owing to its connection to the coast with interior states. With the introduction of European trade after fifteenth century AD, Kombo became important region for traders, Manding conquerors and wandering Islamic clerics [16]. The period of 1856 and 1862 was characterized by intense Muslim resistance against Soninke rule in Kombo. It also coincided with the conversion of leading Soninke ruling families. As Skinner examines:

One of the most serious defections from the Bojang rulers occurred in Brikama in 1863. The suma (senior elder) of Brikama was Madi Nyenkeleng, brother of the late Mansa Jomba Bojang. Madi Nyenkeleng was the tax collector forMansa Koli, but he and other notables had a disagreement with the Mansa. As a result of the dispute Madi Nyenkeleng fled to Gunjur with several kegs of powder entrusted to him by the Soninké ruler when Ma Ba Jakhu had threatened Kombo in May 1863. In Gunjur Madi Nyenkeleng converted to Islam, hired 100 men from Fodé Kaba Turé (paid for by the gunpowder), captured Manduwari, built a stockade, and declared "holy war" on Brikama in January 1864.

The intensification of Muslim resistance disrupted the trade. This required the intervention of the British. In addition, it also required additional justification necessary to convince the British government to provide military support. The report sent to the colonial office confirms the position of British administration. The report states that "In Kombo, the original inhabitants were Soninkes. They were conquered after the protracted war which began in the 1850s. The Soninke kings earlier on controlled the economic and political spheres of the region. The kings of Kombo and the ruling families, from which the kings were elected, were all Soninkes." 11 However, the minority marabout elements in Kombo had gradually gained ground in their various settlements. Significantly, the Marabouts were in their greatest strength in Gunjur, Sukuta and Brefet (Brufut). The success of the Muslims revolution in Kombo can be explained in the context of institutional transformation that gave rise to effective conscietization and material mobilization in course Islamic awakening. Quinn observes the resultant eminent manifestation of this situation through Islamic practice and the establishment of religious infrastructures [12] .During the mid-nineteenth century, the mosque in Sukuta was considered the largest in Senegambia. The Muslims in all these settlements firmly established themselves against Soninke political hegemony in 1855. This however, posed a threat to the regime of Suling Jatta, a Soninke king at Busumbala. Mansa Suling therefore sought the protection of the British administration. Despite the presence of the Europeans the marabouts of Gunjur attacked Busumbala in 1855 and killed Suling Jatta. This marked the weakening of Soninke political hegemony, and the rise of the dominance of Muslim clerics in Kombo.

In 1873, the Marabouts or strict Mohammedans elected Foday Sillah as their war general. Though, he was not acknowledged by all the ruling houses in Kombo. His emergence came to represent the Muslim resistance against the regime of Mansa Sisi Bojang(King) in Brikama [16]. He was able to establish alliances with other Muslim

\footnotetext{
${ }^{11}$ csol/118
} 
settlements in Kombo to attack and overthrow the existing Soninke hegemony in Kombo. ${ }^{12}$ When Foday Sillah became a new Emir, his volunteers are not from only Kombo but entire region of Senegambia. Some warriors are believed to be what J.M. Gray described as 'lawless Adullamites, whose ideals were anarchical rather than religious"[1]. Foday Kombo Sillah successfully subdued all the Soninkeh villages of Kombo and established Islamic monarchical based administration until 1894.

\section{FUlani MigRATION: CREATION OF FUlladU Kingdom AND THE MIGRATION OF POPULAR CLERICS}

In the fifteenth century, Koli Tenguella led the Fula migration into both banks of Senegambia. They crossed The Gambia and conquered several territories. They established Denyanke dynastic rule from the fifteenth to nineteenth centuries. This migration from north, east and south made both banks of The Gambia important settlements for Fulas in the nineteenth century. The migrant Fulas lived in small scattered settlements of the south bank region of Tomana, Kantora and Jimara under the political dominance of the Mandingos for almost a century[12].

The Fulani migration was ecological driven. The land was covered by thick forests which enhanced the practice of shifting cultivation. It also had a rich grazing land used by pastoralists as well as a minimal obstacle for nomadic and fighting men.Though the Fulas and Mandinkas co-existed, it is confirmed that the Mandinka kings exploited the Fulas. By the middle of the nineteenth century, the Fulas were determined to rebel and end the oppressive rule of the Mandinka kings. The mobilization of Fulani rebellion was conducted within the framework of triple alliance. The combined forces of the Fulas from Futa Jallon and the Fulbe Firdu led by Alfa Molloh and Momodu Salif, the remaining territories of Jimara, Tomana, Eropina, Pata, Kamako, Yega and Fambanta were conquered. The Fulas achieved this success after the defeat of the Mandinka chief, Lekuta Sona, near the French station at Kolda [1]. Consequently, this led to the creation of new polity known as Fulladu under Alfa Molo. The establishment of Fulladu symbolized the success of regional agenda of Futa Imamate.

Some of these Fula kings even had cordial relations with the British. In 1882, the king of Futa Jallon, Jalakoto, and Timbo signed peace treaties with the British. ${ }^{13}$

The defeat and conquest by the Fulas, the territories of Jimara, Tomana, Pata, Kamako, Yega and Fambanta experienced the migration of popular clerics. The migration of Muslim in the south bank region was politically and economically driven. The later part of $19^{\text {th }}$ century coincided with major political events in the world. Consequently, the commitment of major European powers experiencing economic slump were making effort to intensify trade with newly acquired territories in Africa. Gambia became part of these wider global realities during

\footnotetext{
${ }^{12}$ CSO1 The Draft Dispatches to colonial Office , Piece 118, Gambia National Archive, Banjul.(NRS)

${ }^{13}$ Cso1/22, Draft dispatches to Colonial office, piece 118, National Archive, (NRS) Banjul
}

the height of legitimate trading system[11]. It also led to corresponding intensification of internal struggle and competition between Soninke aristocracy and Muslim migrant over the control of strategic zones.

The new trading system motivated some Muslim warriors to mobilize human and material resources to create their own independence. In the upper Gambian valley peanut production played a key role in that competition. In the 1870s, a well-known Jahanke cleric known as Foday Bakary and his son Foday Kaba Dumbuya migrated to Fulladu. Foday Kaba and his father migrated from Bundu Gumbel and settled for some time at Koss in Wuli. Foday Kaba and his father later proceeded to Borro and Chakunda, the base of one of the Soninke lieutenants under Kelefa Meseng, the Nyancho at Suma Kunda, a Soninke subcapital. ${ }^{14}$ Kelefa Meseng, the Soninke chief, offered them a place to settle near the River. They named this home Kerewan Dumbokono. Few years later, people began to join them. As the settlement grew larger, they built their fortress and cleared another place near the River bank called Pirrif. As a self-claimed custodian of the land at Pirrif, all the settlers paid taxes to his father in the form of food, materials and gun powder, which they stored in case of any eventuality. ${ }^{15}$

\section{SPIRITUAL AND Militant WAR}

The narratives of all the holy warriors in the Gambia indicate both military and spiritual miracle mobilization employed to weaken the Soninke authorities. In his exploration of spiritual and militant jihad, Skinner identifies two version of miracle mobilization explored by Muslim warrior in Kombo, Foday Sillah. Accordingly, he put nasos (liquid charm) powder and water and threw Koriteh (dangerous aggressive charm) into the well of Soninkes. The narrative of Foday Kaba examines how Foday Kaba manipulated miracle mobilization to facilitate his penetration into non-Muslim settlements [15]. According to narratives, Foday Kaba Dumbuya first attacked Dobang Kunda. Tradition holds that Kaba fed a black bull with a concoction locally called naso in Mandinka and safara in Wollof, in order to weaken the Soninke of Dobang Kunda spiritually. This was offered to the people of Dobong Kunda who, on receiving the bull, gathered at the village public space (or bantaba) to examine the bull. So a woman who was suspicious told the gathering that the offer was meant for evil. Therefore, this woman left saying, "this will never be slaughtered in my presence". The inhabitants, taking no heed of the woman's advice, slaughtered the bull and feasted on it. Consequently, they all slumbered away. On learning this, Foday Kaba and his soldiers succeeded in invading Dobong Kunda without much effort. He captured some as slaves, decapitated others and threw their heads into a River called Alikiyama Bolong (the river of the Day of Judgment).

\footnotetext{
14 Socio-historical Fact Finders Society, Gambia News Bulletin, No.50,Part.III, $24^{\text {th }}$ May, 1969, (Archive of the Gambia) p.2.

${ }_{15}$ According to Jali Suso, more than 40 elders came out with their knives on their heads, demonstrating their readiness for conversion. Foday Kaba Dumbuya and his warriors decided to shave their heads. Each man they shaved was slaughtered and then proceeded to raze their town.
} 
District, West Coast Region.

\section{CONCLUSION}

It is understood that motivation of migration into the south bank of The Gambia was both ecologicaly and politically driven. The period of $19^{\text {th }}$ century witnessed greater demographic change which became a potential source of intense struggle among various migrating forces over the control of new emerging political and economic phenomena. These conflicts could be rationalized from perspective of economic, ethnic and religious dimension. Significantly, conflict in Foni was ecologically driven. The availability of flood-recession and arable field did not only serve as pull factor for incoming population, but also served as potential source of inter-ethnic conflict between the Bainunkas and the Jolas in Foni. Consequently, this led to the dominance of Jolas, and the eventual acculturation of early Bainunka settlers into Jola ethnic group in Foni.

It is significant to analyze political transformations of south bank region within the framework of changes in the global economic system. Therefore, the abolition of transatlantic slave trade and the subsequent introduction of legitimate trading system led to political struggle between the Fulas and Mandingos over the control of strategic rivers. This led to the establishment of tactical ethnic alliances and alignments among various Fulani groups from Bundu, Firdu and Labe against the Mandingo dominance.

Ultimately, it is clearly demonstrated that the migration of Muslim clerics and their followers into south bank led to political revolution that changed the political map of the south bank. Therefore, in the analysis we can infer that transformation in the later part of $19^{\text {th }}$ century in the south bank region of the Gambia cannot be contextualized in history without putting it into broader historical framework.

\section{APPENDIX ORAL INTERVIEWS}

I conducted all oral interviews in several places in the south bank of the Gambia.

Bojang, Sutay. A member of the founding family in Sangajour. Interviewed on 11 January 2009 in Sangajour village, Foni Kansala District.

Fatty, Sako. He is the descendant of Bondali Fatty, a migrant Mandinka cleric and trader, resides at Bondali Tenda. Interviewed on 11 January 2009 in Foni Bondali, Foni Bondali District, West Coast Region.

Jarju, Landing. A former World War II veteran, residing at Bwiam Kangkuntu. Interviewed on 11 January 2009 in Foni Kansala District.

Jarju, Ousman. A farmer currently residing at Kanfenda. Interviewed on 10 January 2009 in Kanfenda, Foni Kansala District.

Kolly, Bintou. Granddaughter of Gassamanga Kolly, the founder of Bondali. Interviewed on 11 January 2009 in Foni Bondali, Foni Bondali District, West Coast Region.

Sanneh, Fa Sarjo. Interviewed on 3 March 2009 in Kiang Battelling, Central Kiang.

Touray, Pa Malick. Kabilo or ward head in Gunjur Konoto Ward. He is also a former World War II veteran. Interviewed on 23 August 2009 in Gunjur, Kombo South

\section{REFERENCES}

[1] J. M. Gray, A History of The Gambia, London: Frank CASS, 1966, p. 327

[2] J. Searing, "No kings, no lords, no slaves: Ethnicity and religion among the sereer- safen of western bawol 1700-1914," Journal of African History, vol. 43, 2002, p. 423.

[3] B. Boubacarr, Senegambia and the Atlantic Slave Trade, Cambridge: Cambridge University Press, 1998, p. 19.

[4] P. Mark, Portuguese Style and Luso-African Identity, Indiana: Indiana University Press, 2002.

[5] D. P. Gamble, The South Bank of The Gambia: The Places, People, and Population, The Foni Districts, Brisbane: California. May 1997, d7.

[6] R. M. Baum, "Shrines, medicines, and the strength of the head: The way of the warrior among the diola of senegambia," Numen, vol. 40, no. 3,1993 , p. 3.

[7] D. R. Wright, "Beyond migration and conquest: Oral traditions and mandinka ethnicity in senegambia," History in Africa, vol. 12, Cambridge University Press, 1985, pp. 335-348.

[8] O. Nnoli, Ethnic Conflict in Africa: A Comparative Analysis, Dakar: CODESRIA, 1998, p. 11.

[9] S. G. Egwu, "Agrarian question and rural ethnic conflict in Nigeria," in Ethnic Conflict in Africa, O. Nnoli, Ed. Dakar: CODESRIA, 1998, pp. 53-79.

[10] C. B. Brettell and J. F. Hollifield, Eds. Migration Theory: Talking Across Disciplines, $2^{\text {nd }}$ ed. New York and London: Routledge, 2008.

[11] D. R. Wright, The World and a Very Small Place in Africa: A History of Globalization in Nuimi, The Gambia, 2nd ed. Armonk: M. E. Sharpe, pp. 110, 135.

[12] C. A. Quinn, Mandinka Kingdom of Senegambia: Traditionalism Islam, and European Expansion, evanston: Northwestern University Press, 1972

[13] D. Robinson, Paths of Accommodation: Muslim Societies and French Colonial Authorities in Senegal and Mauritania, 1880-1920, Athens, Ohio: Ohio University Press, 2000, p. 16.

[14] Lamin Sanneh, "Islam and the Jakhanke people of West Africa," Journal of International African Institute, vol. 46, no. 1, 1970, p. 84.

[15] Mamdani Mahmood, Citizen and Subject: Contemporary Africa and the Legacy of Late Colonialism, Princeton, NJ: Princeton University Press, 1996, pp. 45.

[16] D. E. Skinner, "Islam in Kombo: The spiritual and militant Jihād of Fodé ibrahim silla turé," Islamic Africa, vol. 3, no. 1, Brill, Northwestern University Press, pp. 87, 126, 2012.

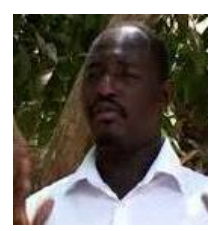

Essa Touray is a prominent Gambian historian and scholar. He obtained his bachelor of arts degree in history and english in 2004 and $\mathrm{He}$ obtained his master's degree in 2007 from the University of The Gambia. He majored in African History and wrote a thesis titled: "Foday Kaba: Nation Building and The Colonial Encounter 1875-1901.”

Currently, Touray is a lecturer in African History at the School of Arts and Humanities at the University of The Gambia. His areas of expertise include, Africa in Global History; Problem of Nation Building in Africa since Independence, and West African States and Empires. Mr. Touray also delivered several academic papers at both local and international fora. In 2015, he delivered a paper on "Anglo-French Boundary Commission and the British Military expedition Against Foday Kaba and His Allied 1891-1898," during the Early Bird Round of Third International Conference on Advances in Economics, Social Science and Human Behaviour Study in Bangkok, Thailand. In 2014, he also delivered a paper on "Africa in the Historical Context of Globalization: From Medieval to Modern Era during a conference organized by Global Hand, United Kingdom. His many academic researches include; "Kombo Before the Colonial Era, Early Establishments and Socio-political Transformation.'

Mr. Touray is also a member of several professional organizations, including, Council for The Development of Social Science Research in Africa (CODESRI), as well as Athens Institute for Education and Research and Institute of Research Engineers and Doctors, USA.. His insightful and indebt knowledge about African history has led him to carry our periodic academic research works in neighboring West African countries. 